\title{
K-Gram As A Determinant Of Plagiarism Level In Rabin-Karp Algorithm
}

\author{
Andysah Putera Utama Siahaan, Mesran, Robbi Rahim, Dodi Siregar
}

\begin{abstract}
Rabin-Karp is one of the algorithms used to detect the similarity levels of two strings. In this case, the string can be either a short sentence or a document containing complex words. In this algorithm, the plagiarism level determination is based on the same hash value on both documents examined. Each word will form K-Gram of a certain length. The K-Gram will then be converted into a hash value. Each hash value in the source document will be compared to the hash value in the target document. The same number of hashes is the level of plagiarism created. The length of $\mathrm{K}$ Gram is the determinant of the plagiarism level. By determining the proper length of K-Gram, it produces the accurate result. The results will vary for each K-Gram value.
\end{abstract}

Index Terms: Text Mining, Plagiarism, Similarity

\section{INTRODUCTION}

Rabin-Karp algorithm is an algorithm that is often used to determine whether a document is a plagiarism of other documents [1][2]. This algorithm works by determining the values of the existing snippets in the source and target documents. The more the same value on both documents, the higher the plagiarism level of the document [3][4]. But the plagiarism value of the two documents is not always the same. $\mathrm{K}$-Gram is the determinant of the accuracy of a plagiarism analysis. The problem is how to determine this value correctly to approach a high accuracy value. The value of K-Gram will be different for each language used on the documents to be compared. This value is seen by looking at how short the number of characters used in each document. English will be more likely to match the small value of K-Gram compared to Bahasa Indonesia. K-Gram is often a dilemma to determine the truth of a document. Not always this value produces reality. The disadvantage of document comparisons is the inability of an application to determine which documents are correct and which documents first come to the surface. But this method can help an analyst to determine the level of similarity of some documents based on the value of K-Gram used. This study aims to compare the value of K-Gram used against several documents. From these calculations, it can be seen which KGram values are more suitable for a particular case.

- Andysah Putera Utama Siahaan, Mesran, Robbi Rahim, Dodi Siregar

- Faculty of Computer Science, Universitas Pembanguan Panca Budi, Medan, Indonesia

- Department of Computer Engineering, STMIK Budi Darma, Medan, Indonesia

- Department of Health Information,, Akademi Perekam Medik dan Infokes Imelda, Medan, Indonesia

- Department of Informatics, Sekolah Tinggi Teknik Harapan, Medan, Indonesia

- Student of Universiti Malysia Perlis, Kangar, Malaysia

\section{Related Work}

In 2014, Ashish Prosad Gope and Rabbi Narayan Behera conducted research on Rabin-Karp's relationship with DNA. Each DNA has its own sequence. This study is a field of bioinformatics. DNA sequence is a sequence of characters that have a certain length to determine the nucleotides present in the DNA. In this sequence, some information related to the disease in humans is obtained. This sequence has a certain pattern so that an algorithm is needed to match the pattern [6]. This study evaluated four performance pattern matching algorithms and then produced a new algorithm based on Rabin Karp's algorithm. This technique ensures that the comparison of characters can be eliminated from the RabinKarp algorithm. This algorithm looks for the patterns specified in a large set of DNA sequences [6].

\subsection{Example of Improved Rabin-Karp}

The following figure is an example of the development of the Rabin-Karp algorithm developed by both researchers.

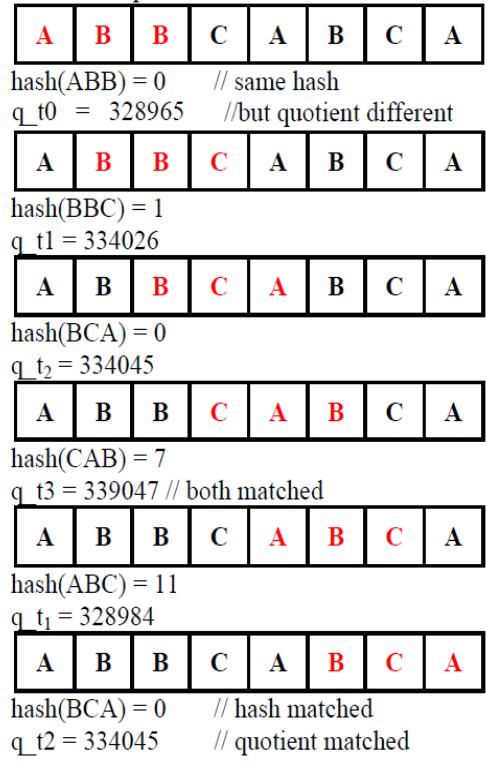

Fig. 1 Improved Rabin-Karp Algorithm

Figure 1 describes since the hash $=0$ and quotient $=334045$, both matched. Only "BCA" pattern is matched. And hash (ABB) $=0$ and quotient $=328965$, which has not matched, $A B B$ is not compared. In some problems, this algorithm has no significant 
difference with the pure Rabin-Karp algorithm. The complexity of this algorithm can be significantly improved [5]. The complexity of time during the worst case is $O((n-m+1) m)$ to $\mathrm{O}(\mathrm{nm}+1)$. The complexity of this time depends on the prime number being the modulo. Choosing the right prime number will improve the optimization is good [6].

\section{IMPLEMENTATION}

Some steps must be taken before generating plagiarism value. Not all words will be used as input. These processes are Tokenizing, Filtering and Stemming. This should be done to streamline words and discard words that do not become keywords in comparison.

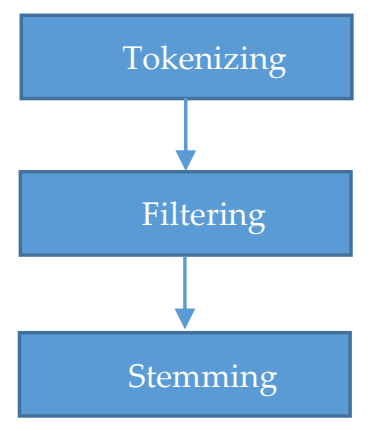

In this section, it will be examined two different sentences. The experiment will be done several times with different K-Gram values. The first sentence is "plagiarism is an act or instance of using or closely imitating the language and thoughts of another author without authorization". The second sentence is "plagiarism is an act of copying the ideas or words of another person without giving credit to that person".

Table 1 Word Extraction

\begin{tabular}{|c|c|}
\hline First Sentence & Second Sentence \\
\hline plagiarism & plagiarism \\
\hline instance & copying \\
\hline using & ideas \\
\hline closely & words \\
\hline imitating & another \\
\hline language & person \\
\hline thoughts & without \\
\hline another & giving \\
\hline author & credit \\
\hline without & that \\
\hline authorization & person \\
\hline
\end{tabular}

Table 1 illustrates the extraction of important words from the first and second sentences. Not all words will be taken from a sentence. Some processes must be skipped so as to produce important words only.

\section{1 $\mathrm{K}-\mathrm{Gram}=10$}

Table $2 \mathrm{~K}$-Gram $=10$

\begin{tabular}{|c|c|c|c|}
\hline $\begin{array}{c}\text { 1st } \\
\text { Sentence }\end{array}$ & Hash & $\begin{array}{c}\text { 2st } \\
\text { Sentence }\end{array}$ & Hash \\
\hline plagiarism & 7208 & plagiarism & 7208 \\
\hline lagiarismi & 3721 & lagiarismc & 3715 \\
\hline agiarismin & 8470 & agiarismco & 8411 \\
\hline giarismins & 9795 & giarismcop & 9202 \\
\hline iarisminst & 3653 & iarismcopy & 7735 \\
\hline arisminsta & 2463 & arismcopyi & 3263 \\
\hline risminstan & 9762 & rismcopyin & 7755 \\
\hline isminstanc & 9448 & ismcopying & 9396 \\
\hline sminstance & 375 & smcopyingi & 9866 \\
\hline minstanceu & 759 & mcopyingid & 5589 \\
\hline instanceus & 3976 & copyingide & 2227 \\
\hline nstanceusi & 5701 & opyingidea & 7596 \\
\hline stanceusin & 8463 & pyingideas & 2504 \\
\hline tanceusing & 1569 & yingideasw & 6730 \\
\hline anceusingc & 7781 & ingideaswo & 4882 \\
\hline nceusingcl & 2898 & ngideaswor & 4763 \\
\hline ceusingclo & 448 & gideasword & 9080 \\
\hline eusingclos & 9838 & ideaswords & 6509 \\
\hline usingclose & 3861 & deaswordsa & 1002 \\
\hline singclosel & 5796 & easwordsan & 466 \\
\hline ingclosely & 4938 & aswordsano & 214 \\
\hline ngcloselyi & 5314 & swordsanot & 7292 \\
\hline gcloselyim & 4592 & wordsanoth & 9874 \\
\hline closelyimi & 1647 & ordsanothe & 6084 \\
\hline loselyimit & 1815 & rdsanother & 7397 \\
\hline oselyimita & 9411 & dsanotherp & 5825 \\
\hline selyimitat & 641 & sanotherpe & 8659 \\
\hline elyimitati & 3407 & anotherper & 3540 \\
\hline lyimitatin & 9609 & notherpers & 523 \\
\hline yimitating & 7301 & otherperso & 6719 \\
\hline imitatingl & 582 & therperson & 3736 \\
\hline mitatingla & 1774 & herpersonw & 9457 \\
\hline itatinglan & 4114 & erpersonwi & 5369 \\
\hline tatinglang & 7079 & rpersonwit & 9221 \\
\hline atinglangu & 2857 & personwith & 4043 \\
\hline tinglangua & 3682 & ersonwitho & 2098 \\
\hline inglanguag & 8901 & rsonwithou & 6533 \\
\hline nglanguage & 4912 & sonwithout & 7196 \\
\hline glanguaget & 579 & onwithoutg & 8913 \\
\hline languageth & 1544 & nwithoutgi & 5657 \\
\hline anguagetho & 6715 & withoutgiv & 8031 \\
\hline nguagethou & 2254 & ithoutgivi & 7672 \\
\hline guagethoug & 4007 & thoutgivin & 2638 \\
\hline uagethough & 5803 & houtgiving & 8468 \\
\hline agethought & 5210 & outgivingc & 5480 \\
\hline gethoughts & 7216 & utgivingcr & 1357 \\
\hline ethoughtsa & 7865 & tgivingcre & 763 \\
\hline thoughtsan & 4154 & givingcred & 9729 \\
\hline houghtsano & 3622 & ivingcredi & 2982 \\
\hline oughtsanot & 7072 & vingcredit & 5779 \\
\hline ughtsanoth & 7260 & ingcreditt & 70 \\
\hline ghtsanothe & 9758 & ngcreditth & 6668 \\
\hline htsanother & 3281 & gcredittha & 8113 \\
\hline tsanothera & 3643 & creditthat & 6847 \\
\hline sanotherau & 8525 & reditthatp & 3776 \\
\hline anotheraut & 2202 & editthatpe & 9632 \\
\hline
\end{tabular}




\begin{tabular}{|c|c|c|c|}
\hline notherauth & 7146 & ditthatper & 1814 \\
\hline otherautho & 2900 & itthatpers & 8591 \\
\hline therauthor & 5578 & tthatperso & 1822 \\
\hline herauthorw & 7863 & thatperson & 315 \\
\hline erauthorwi & 9443 & & \\
\hline rauthorwit & 9933 & & \\
\hline authorwith & 1156 & & \\
\hline uthorwitho & 6700 & & \\
\hline thorwithou & 4174 & & \\
\hline horwithout & 3827 & & \\
\hline orwithouta & 9103 & & \\
\hline rwithoutau & 7569 & & \\
\hline withoutaut & 7549 & & \\
\hline ithoutauth & 2851 & & \\
\hline thoutautho & 4464 & & \\
\hline houtauthor & 6725 & & \\
\hline outauthori & 8070 & & \\
\hline utauthoriz & 7251 & & \\
\hline tauthoriza & 9664 & & \\
\hline authorizat & 8692 & & \\
\hline uthorizati & 1998 & & \\
\hline thorizatio & 7183 & & \\
\hline horization & 3890 & & \\
\hline & & & \\
\hline
\end{tabular}

The table above shows the hash value of $\mathrm{K}-\mathrm{Gram}=10$. From the hash values generated by each sentence, the same values will be obtained. There are 79 hash values in the first sentence and there are 60 hash values in the second sentence. So the total hash is 139 . There is only one has same value in both tables. The value is 7208 . This calculation can be seen below:

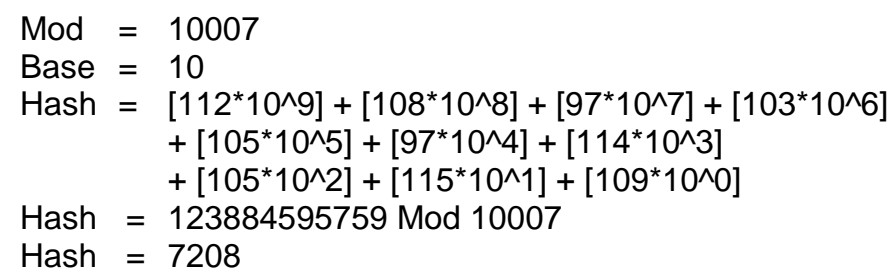

The calculation of the plagiarism level does not end at the hash value only. There is a formula for determining the percentage of similarity of the two comparable documents. The formula used is as follows:

$$
\mathrm{P}=\frac{2 * \mathrm{SH}}{\mathrm{THA}+\mathrm{THB}} * 100 \%
$$

Where:

$$
\begin{aligned}
& \mathrm{P}=\text { Plagiarism Rate } \\
& \mathrm{SH}=\text { Identical Hash } \\
& \text { THA }=\text { Total Hash in Document } \mathrm{A} \\
& \mathrm{THB}=\text { Total Hash in Document } \mathrm{B}
\end{aligned}
$$

In the previous calculation there is one hash that has the same

\begin{tabular}{|c|c|c|c|}
\hline $\begin{array}{c}\text { 1st } \\
\text { Sentence }\end{array}$ & Hash & $\begin{array}{c}\text { 2st } \\
\text { Sentence }\end{array}$ & Hash \\
\hline plagi & 7974 & plagi & 7974 \\
\hline lagia & 7621 & lagia & 7621 \\
\hline agiar & 3828 & agiar & 3828 \\
\hline giari & 5147 & giari & 5147 \\
\hline iaris & 8760 & iaris & 8760 \\
\hline arism & 4996 & arism & 4996 \\
\hline rismi & 6820 & rismc & 6814 \\
\hline ismin & 6241 & ismco & 6182 \\
\hline smins & 9833 & smcop & 9240 \\
\hline minst & 6426 & mcopy & 501 \\
\hline insta & 1938 & copyi & 2738 \\
\hline nstan & 6826 & opyin & 4399 \\
\hline stanc & 6010 & pying & 1828 \\
\hline tance & 8209 & yingi & 6211 \\
\hline anceu & 264 & ingid & 631 \\
\hline nceus & 9545 & ngide & 3754 \\
\hline ceusi & 3185 & gidea & 5309 \\
\hline eusin & 8869 & ideas & 373 \\
\hline using & 5800 & deasw & 1192 \\
\hline singc & 6247 & easwo & 9024 \\
\hline ingcl & 579 & aswor & 7361 \\
\hline ngclo & 3244 & sword & 444 \\
\hline gclos & 227 & words & 2598 \\
\hline close & 9581 & ordsa & 4386 \\
\hline losel & 2778 & rdsan & 1705 \\
\hline osely & 5440 & dsano & 5127 \\
\hline selyi & 2233 & sanot & 8351 \\
\hline elyim & 468 & anoth & 1601 \\
\hline Iyimi & 1848 & nothe & 2887 \\
\hline yimit & 6142 & other & 6663 \\
\hline imita & 9945 & therp & 4463 \\
\hline mitat & 6846 & herpe & 2816 \\
\hline itati & 6146 & erper & 5533 \\
\hline tatin & 8878 & rpers & 2473 \\
\hline ating & 6940 & perso & 2800 \\
\hline tingl & 6249 & erson & 5929 \\
\hline ingla & 658 & rsonw & 6437 \\
\hline Nglan & 4033 & sonwi & 2406 \\
\hline Glang & 8105 & onwit & 2205 \\
\hline langu & 8321 & nwith & 9910 \\
\hline angua & 804 & witho & 6841 \\
\hline nguag & 4926 & ithou & 6808 \\
\hline guage & 7026 & thout & 5497 \\
\hline uaget & 7537 & houtg & 3151 \\
\hline ageth & 3608 & outgi & 8874 \\
\hline getho & 2953 & utgiv & 6565 \\
\hline ethou & 6836 & tgivi & 3896 \\
\hline thoug & 5484 & givin & 7162 \\
\hline hough & 3022 & iving & 8884 \\
\hline ought & 7595 & vingc & 6226 \\
\hline ughts & 3779 & ingcr & 585 \\
\hline ghtsa & 6049 & ngcre & 3294 \\
\hline htsan & 7768 & gcred & 712 \\
\hline tsano & 5015 & credi & 4428 \\
\hline sanot & 8351 & redit & 1291 \\
\hline anoth & 1601 & editt & 992 \\
\hline
\end{tabular}
value. So the plagiarism level calculation is as follows.

$$
\begin{aligned}
\mathrm{P} & =\frac{2 * 1}{79+60} * 100 \% \\
& =\frac{2}{139} * 100 \% \\
& =0,0143884892086331 * 100 \% \\
& =1,439 \%
\end{aligned}
$$

\section{$3.2 \mathrm{~K}-\mathrm{Gram}=5$}

Table $2 \mathrm{~K}$-Gram = 5 


\begin{tabular}{|c|c|c|c|}
\hline nothe & 2887 & ditth & 7087 \\
\hline other & 6663 & ittha & 7918 \\
\hline thera & 4448 & tthat & 6590 \\
\hline herau & 2682 & thatp & 4083 \\
\hline eraut & 4195 & hatpe & 9023 \\
\hline rauth & 9096 & atper & 7561 \\
\hline autho & 8988 & tpers & 2459 \\
\hline uthor & 6721 & perso & 2800 \\
\hline thorw & 5470 & erson & 5929 \\
\hline horwi & 2883 & & \\
\hline orwit & 6205 & & \\
\hline rwith & 9882 & & \\
\hline witho & 6841 & & \\
\hline ithou & 6808 & & \\
\hline thout & 5497 & & \\
\hline houta & 3145 & & \\
\hline outau & 8826 & & \\
\hline utaut & 6083 & & \\
\hline tauth & 9082 & & \\
\hline autho & 8988 & & \\
\hline uthor & 6721 & & \\
\hline thori & 5456 & & \\
\hline horiz & 2760 & & \\
\hline oriza & 4956 & & \\
\hline rizat & 7411 & & \\
\hline izati & 2139 & & \\
\hline zatio & 8837 & & \\
\hline ation & 6957 & & \\
\hline
\end{tabular}

The table above shows the hash value of $\mathrm{K}-\mathrm{Gram}=5$. There are 84 hash values in the first sentence and there are 65 hash values in the second sentence. So the total hash is 149 . There are 13 values have the same value in both tables. The plagiarism calculation can be seen below:

$$
\begin{aligned}
\mathrm{P} & =\frac{2 * 13}{84+65} * 100 \% \\
& =\frac{26}{149} * 100 \% \\
& =0,174496644295302 * 100 \% \\
& =17,449 \%
\end{aligned}
$$

\section{Conclusion}

The determination of the value of K-Gram greatly affects the percentage of truth plagiarism level. Every language in the world has different K-Gram values. For higher K-Gram values tend to have a low level of similarity, while lower K-Gram values increase the percentage of similarity. But this is not absolute as a determinant of the document's authenticity. This method can help analysts to see more about the techniques used to compare documents. Determination of K-Gram requires correct consideration so that the value will be more accurate. This method is only used to help experts in analyzing. All decisions will return to the specialist.

\section{REFERENCES}

[1]. S. K. Shivaji and P. S., "Plagiarism Detection by using Karp-Rabin and String Matching Algorithm Together," International Journal of Computer Applications, vol. 116, no. 23, pp. 37-41, 2015.
[2]. M. Cebrián, M. Alfonseca and A. Ortega, "Towards the Validation of Plagiarism Detection Tools by Means of Grammar Evolution," IEEE Transactions on Evolutionary Computation, vol. 13, no. 3, pp. 71-77, 2009.

[3]. A. Parker and J. O. Hamblen, "Computer Algorithm for Plagiarism Detection," IEEE Trans. Education, vol. 32, no. 2, pp. 94-99, 1989.

[4]. A. Apostolico, String editing and Longest Common Subsequences, vol. 3, Germany: Springer-Verlag, 1997, pp. 1-10.

[5]. Sunita, R. Malik and M. Gulia, "Rabin-Karp Algorithm with Hashing a String Matching Tool," International Journal of Advanced Research in Computer Science and Software Engineering, vol. 4, no. 3, pp. 389-392, 2014.

[6]. A. P. Gope and R. N. Behera, "A Novel Pattern Matching Algorithm in Genome," International Journal of Computer Science and Information Technologies, vol. 5, no. 4, pp. 5450-5457, 2014. 